\title{
Informace o ORAM
}

\section{JIŘí ŠAJER}

Klíčová slova: havarijní znečištění - okamžitý vnos - jakost vody - 1D modelování - Pearsonovo rozdělení III. typu

\section{SOUHRN}

Odra River Alarm Modul (ORAM) bude součástí projektu NAVAROSO. V posledních dvaceti letech nejsou k dispozici žádné výsledky ze stopovacích pokusů české části řeky Odry. Z toho důvodu byly pro analýzu použity výsledky ze stopovacích pokusů na řece Svitavě. Tento článek je specificky zaměřen na analýzu pěti průnikových křivek. Nejlepší aproximace průnikové křivky ve všech pěti príipadech byla dána rovnicí (5) - Pearsonovým rozdělením III. typu. Počítá se s tím, že výsledky analýzy budou použity při tvorbě ORAM.

\section{ÚVOD}

Pro modelování šiření havarijního znečištění v tocích se obvykle používají 1D modely. Jako př́klady možno uvést Rhine Alarm Model (RAM), Danube Basin Alarm Model (DBAM), Poplachový model Labe (ALAMO), v USA je to např́klad model RiverSpill, v Rusku je možno jmenovat například model řeky Tura. Náš výzkumný ústav pracuje na projektu NAVAROSO. Jedná se o vývoj expertního informačního systému, jehož cílem je vytvoření a naplnění specializovaného databázového softwaru, umožňujícího rychlé poskytování křížově provázaných údajů o tocích, potenciálních znečištovatelích a látkách, které mohou znečištění toků způsobit a tvorba verzí pro stacionární i mobilní zařízení (pro operační systémy Android, iOS a Windows Phone). Tato databáze bude dopIněna modulem umožňujícím hrubý odhad šiření havarijního znečištění vodním tokem. Modul bude testován na řece Odře nad státní hranicí s Polskem pod názvem ORAM (Odra River Alarm Modul) a zaměří se jmenovitě na toky Odra, Olše, Ostravice, Opava a Lučina. Cílem tohoto článku je seznámit čtenáře s některými poznatky, které byly získány během prípravy tohoto modulu.

\section{METODIKA}

Připravuje se modul umožňující odhady šiření havarijního znečištění v toku. $\checkmark$ současné době je nedostatek podrobných údajů o vodních tocích, pro které má modul sloužit, proto se v první fázi modul omezí na metodu predběžných odhadů. Cílem je poskytovat správci toku, vodohospodářskému orgánu, hasičskému záchrannému sboru a dalším zainteresovaným složkám při řešení havarijních situací orientační informace o dobách doběhu čela mraku znečištění do jednotlivých profilů na toku. $\vee$ prípadech, kdy bude k dispozici odhad množství uniklé znečištující látky při okamžitém vnosu, umožní modul také odhad maximální koncentrace, která pravděpodobně bude dosažena ve zvoleném zájmovém profilu na toku. K predběžným odhadům dotokových dob budou použity empirické rovnice, které jsou výsledkem statistické analýzy velkého množství stopovacích pokusů uvedené v [1]. V budoucnu se počítá se zdokonalením tohoto modulu. To však predpokládá daleko vyšší nároky na přípravu vstupních dat týkajících se vodních toků (geometrie, hydrodynamika, ...), dat pro modelování transportu látek (disperzní součinitele, konstanty kinetiky), apod. Rozsah podkladů potřebný pro takový model je uveden např́klad v [2]. Současná príprava modulu se zaměřuje na tři na sebe navazující kroky. Prvním krokem je predikce dotokových dob, druhým predikce maximální koncentrace $v$ zájmovém profilu a třetím krokem predikce rozdělení koncentrací během průchodu znečištění zájmovým profilem, jinými slovy predikce průnikové křivky $\checkmark$ zájmovém profilu. Dotokové doby mưžeme získat bud' př́mo měřením při stopovacích pokusech, nebo pomocí výpočtů. Výpočty mohou být bud' hydrotechnické, nebo empirické. Empirické vzorce opírající se o hydrologické údaje a údaje ze stopovacích pokusů uvádí například Jobson [1]. Na dolním toku řeky Ostravice a v úseku Odry mezi ústím Ostravice a státní hranicí s Polskem Ize dotokové doby odvodit z kontinuálního měření konduktivity a průtoků ve stanicích Slezská Ostrava a Bohumín a údajů o vypouštění slaných dủlních vod. Problematika dotokových dob je poměrně rozsáhlá a není předmětem tohoto článku. Nejdůležitější dotokové doby jsou znázorněny na obr. 1. Dotoková doba je rozdíl mezi dvěma časy, kde $t_{0}$ je čas okamžitého vnosu, $t_{B}$ je čas, ve kterém znečištění dorazi do zájmového profilu, $t$, je čas, ve kterém znečištění dosáhne 10 \% maximální koncentrace v zájmovém profilu, $t_{p}$ je čas, ve kterém znečištění dosáhne maximální koncentrace v zájmovém profilu, $t_{T}$ je čas, ve kterém znečištění poklesne $10 \%$ maximální koncentrace $v$ zájmovém profilu, $t_{E}$ je čas ve

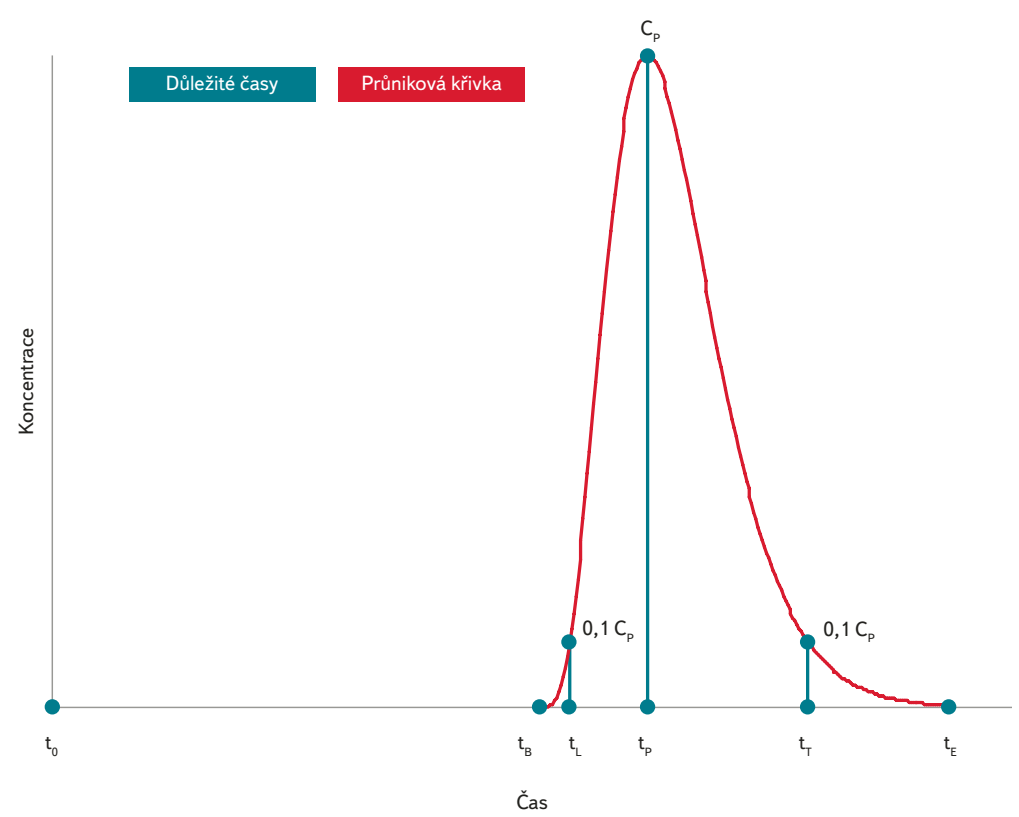

Obr. 1. Důležité dotokové doby Fig. 1. Important travel times 
kterém znečištění opustí zájmový profil a $C_{p}$ je maximální koncentrace znečištující látky dosažená během prưchodu zájmovým profilem ve vzdálenosti $x$ od místa vnosu. Zájmový profil je profil, ve kterém chceme znát maximální koncentraci. Protože časy $t_{B}$ a $t_{E}$ je velice obtížné určit, použivají se $v$ praxi při analýze výsledků stopovacích pokusů časy, ve kterých koncentrace dosáhne $10 \%$ z maximální koncentrace, tyto časy jsou označeny $t_{L}$ a $t_{T}$

Pro predikci maximální koncentrace $v$ prípadě okamžitého vnosu je možno použít vzorec (1) uvedený v DBAM [3]:

$$
C_{p}=\frac{M / Q}{\sqrt{4 \pi D x / U^{3}}} \times \exp \left(-\frac{k x}{U}\right)
$$

kde $C_{p}$ je maximální koncentrace odpovídající vrcholu průnikové křivky ve vzdálenosti $x$ od místa vnosu $\left[\mathrm{g} / \mathrm{m}^{3}\right]$,

M hmotnost vnesené látky [g],

Q prütok ve vzdálenosti $x$ od místa vnosu $\left[\mathrm{m}^{3} / \mathrm{s}\right]$,

U průrezová rychlost $[\mathrm{m} / \mathrm{s}]$,

D koeficient podélné disperze $\left[\mathrm{m}^{2} / \mathrm{s}\right]$,

k rychlostní konstanta 1. rádu charakterizující objemové změny sledované látky [1/s],

t čas [s],

x $\quad$ vzdálenost zájmového od místa vnosu [m].

Další možností je použití empirického vzorce (2). Vychází ze vzorce, který uvádí Jobson [1] a je upraven pro nekonzervativní látku.

$$
C_{p}=\frac{C_{U p} \cdot M}{1 \times 10^{6} \cdot Q} \times \exp \left(-k T_{p}\right)
$$

kde $C_{p}$ je maximální koncentrace odpovídající vrcholu průnikové křivky ve vzdálenosti $x$ od místa vnosu $\left[\mathrm{g} / \mathrm{m}^{3}\right]$,

M hmotnost injektovaného stopovače [g],

Q průtok ve vzdálenosti $x$ od místa vnosu $\left[\mathrm{m}^{3} / \mathrm{s}\right]$,

$C_{u p} \quad$ maximální jednotková koncentrace ve vzdálenosti $x$ od místa vnosu $[1 / \mathrm{s}]$,

k rychlostní konstanta 1. rádu charakterizující objemové změny sledované látky [1/hod].

Jednotková maximální koncentrace je definována jako $10^{6}$ násobek maximální koncentrace při jednotkovém průtoku a jednotkové hmotnosti látky vnesené do toku [1]. Její závislost na dotokové době $T_{p}=t_{p}-t_{0}$ může být vyjádřena empirickou rovnicí (3) uvedenou v [1]:

$$
C_{u p}=1025 \times T_{p}^{-0,887}
$$

nebo rovnicí (4) rovněž uvedenou v [1]:

$$
C_{\text {up }}=857 T_{p}^{-0,760}\left(\frac{Q}{Q_{a}}\right)^{-0,079}
$$

kde $T_{p}=t_{p}-t_{0}$ je dotoková doba odpovídající vrcholu průnikové křivky ve vzdálenosti $x$ od místa vnosu [hod],

Q průtok ve vzdálenosti $x$ od místa vnosu $\left[\mathrm{m}^{3} / \mathrm{s}\right]$,

$Q_{a} \quad$ dlouhodobý průměrný průtok ve vzdálenosti $x$ od místa vnosu $\left[\mathrm{m}^{3} / \mathrm{s}\right]$.
V empirických rovnicích (2), (3) a (4) se uvádějí dotokové doby v hodinách, proto rychlostní konstanta 1. rádu charakterizující objemové změny musí mít $\checkmark$ rovnici (2) rozměr $1 /$ hod.

$\checkmark$ prípadě odhadu maximální koncentrace pro konzervativní látku je rychlostní konstanta 1. rádu charakterizujíci objemové změny sledované látky rovna nule. Pro bezpečný odhad maximální koncentrace při havarijním úniku nekonzervativní látky je nutno zvážit, zda není vhodné položit rychlostní konstantu 1. rádu charakterizující objemové změny rovněž rovnu nule.

Máme-li stanovenu maximální koncentraci $C_{p} \vee$ zájmovém profilu ve vzdálenosti $x$ od místa vnosu, je možno přistoupit k třetímu kroku, a tím je predikce rozdělení koncentrací během průchodu havarijního znečištění zájmovým profilem. V rámci prípravy modulu bylo hledáno takové rozdělení, které co nejvíce odpovídá skutečným hodnotám naměřeným v toku. Byla k tomu použita konkrétní data ze stopovacích pokusů na řece Svitavě [4].

\section{VÝSLEDKY A DISKUSE}

K predikci maximální koncentrace, kterou Ize očekávat během průchodu havarijního znečištění zájmovým profilem, Ize použít rovnici (1) nebo rovnici (2). Obě rovnice mají určité nevýhody. Nevýhodou rovnice (1) je obtižnost správného odhadu koeficientu podélné disperze. V odborné literatuře je totiž doporučeno mnoho různých postupů k určení tohoto koeficientu a výsledky jsou v některých prípadech značně rozdílné. Na nevýhody rovnice (2) upozorňuje ve své diplomové práci Kưrková [5]. Protože v rovnici (2) není zahrnuta podélná disperzivita, mohou se $v$ grafech projevit její změny, především pokud byly zkoušky prováděny na různých místech a při různých průtocích.

Máme-li stanovenu maximální koncentraci $C_{p^{\prime}} \vee$ zájmovém profilu je možno přistoupit k třetímu kroku, a tím je predikce rozdělení koncentrací během průchodu havarijního znečištění zájmovým profilem. $V$ povodí Odry nejsou $\checkmark$ poslední době k dispozici žádné výsledky ze stopovacích pokusů, proto nezbylo, než se při prípravě modelu omezit na data získána odjinud. Různé varianty kroku tři byly ověřovány na konkrétních datech získaných stopovacími pokusy na řece Svitavě [4]. V práci [4] a v navazujících studiích byly průnikové křivky stopovače modelově aproximovány analytickým řešením, resp. za využití numerického modelu (MIKE11). V rámci prípravných studií projektu NAVAROSO byl proveden pokus provést aproximaci průnikové křivky stopovače pomocí Pearsonova rozdělení III. typu, které lze pro časy $t>t_{B}$ vyjádřit pomocí rovnice (5).

$$
C=C_{p}\left(1+\frac{\left(t-t_{p}\right)}{a}\right)^{\frac{a}{b}} \exp \left(-\frac{\left(t-t_{p}\right)}{b}\right)
$$

kde $C$ je koncentrace $v$ čase $t\left[\mathrm{mg} / \mathrm{m}^{3}\right]$,

$C_{p} \quad$ koncentrace odpovídající vrcholu průnikové křivky $\left[\mathrm{mg} / \mathrm{m}^{3}\right]$,

$t^{p} \quad$ čas [s],

$t_{p} \quad$ čas, ve kterém znečištění dosáhne maximální koncentrace v zájmovém profilu [s],

b konstanta odpovídající době mezi $t_{p}$ a časem dosažení těžiště plochy pod průnikovou křivkou [s],

a konstanta odpovídající době mezi $t_{B}$ a $t_{p}[s]$,

$t_{B} \quad$ čas príchodu nejrychlejších částic znečištění do zájmového profilu [s]. 


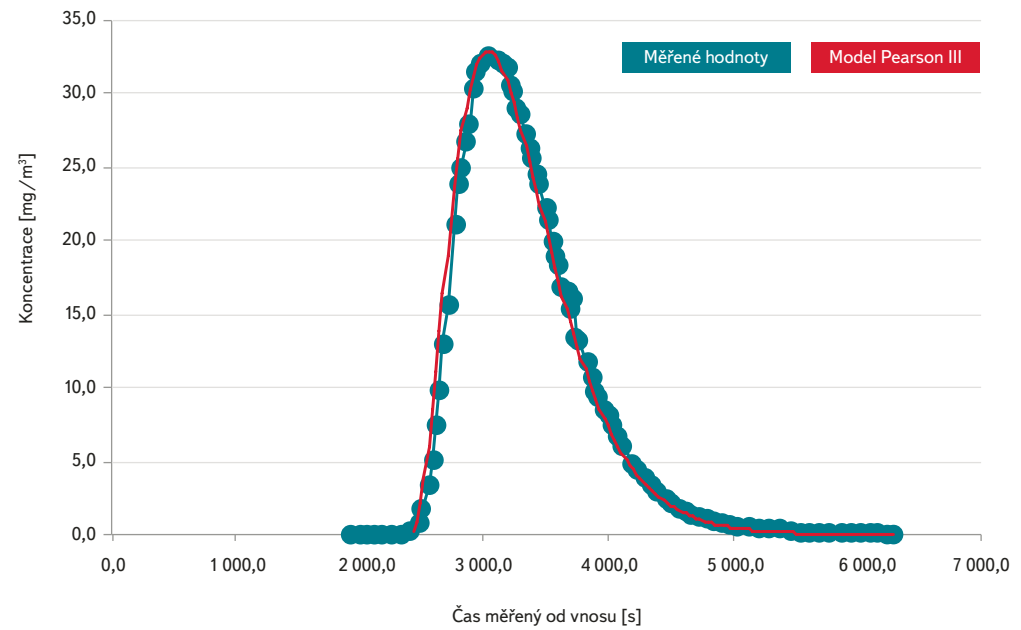

Obr. 2. Průniková kriivka - Svitava PF1 - červen 2000

Fig. 2. Breakthroughcurve - Svitava PF1 - June 2000

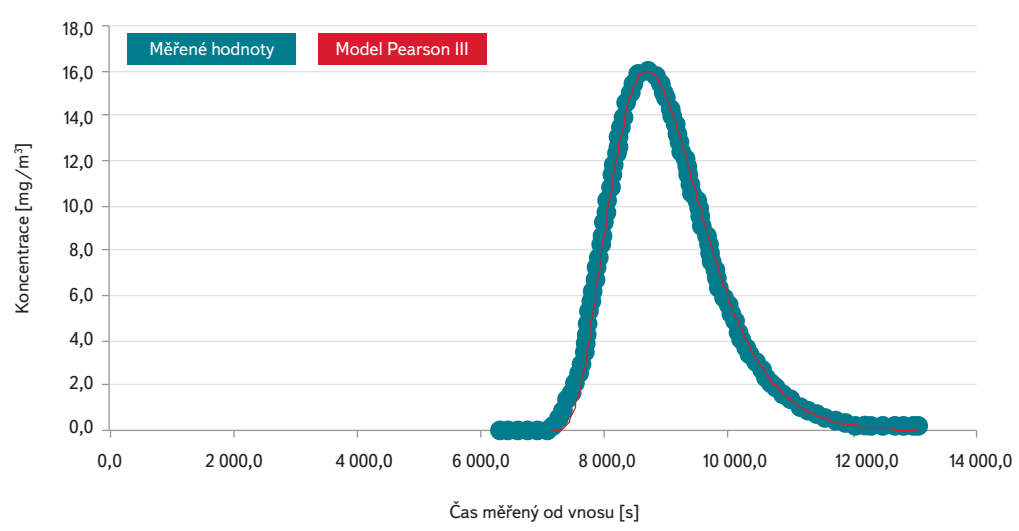

Obr. 3. Průniková krìvka - Svitava PF2 - červen 2000

Fig. 3. Breakthroughcurve - Svitava PF2 - June 2000

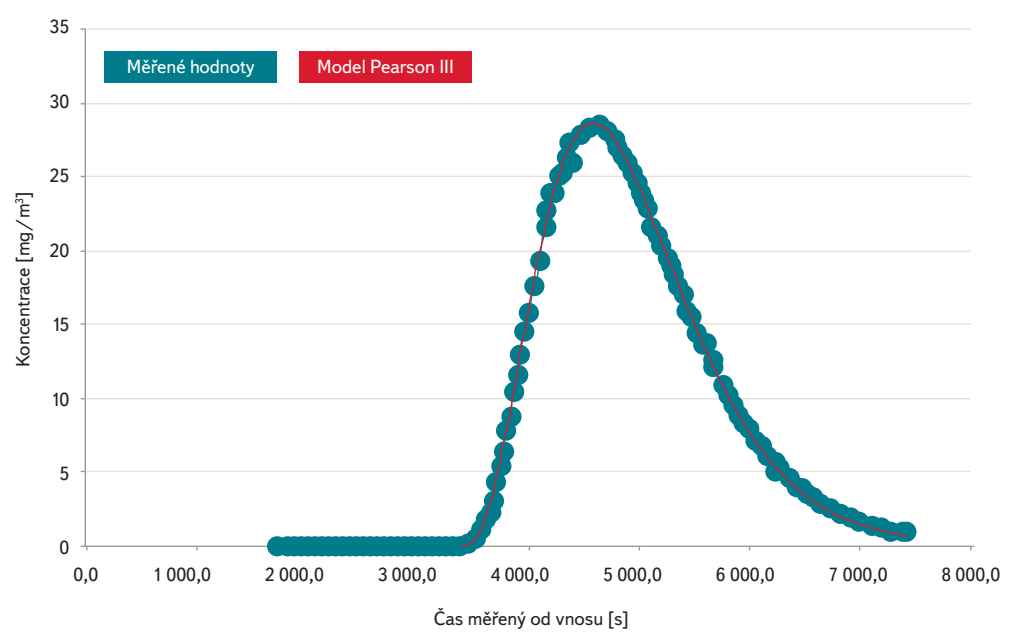

Obr. 4. Průniková křivka - Svitava PF1 - srpen 2000

Fig. 4. Breakthroughcurve - Svitava PF1 - August 2000

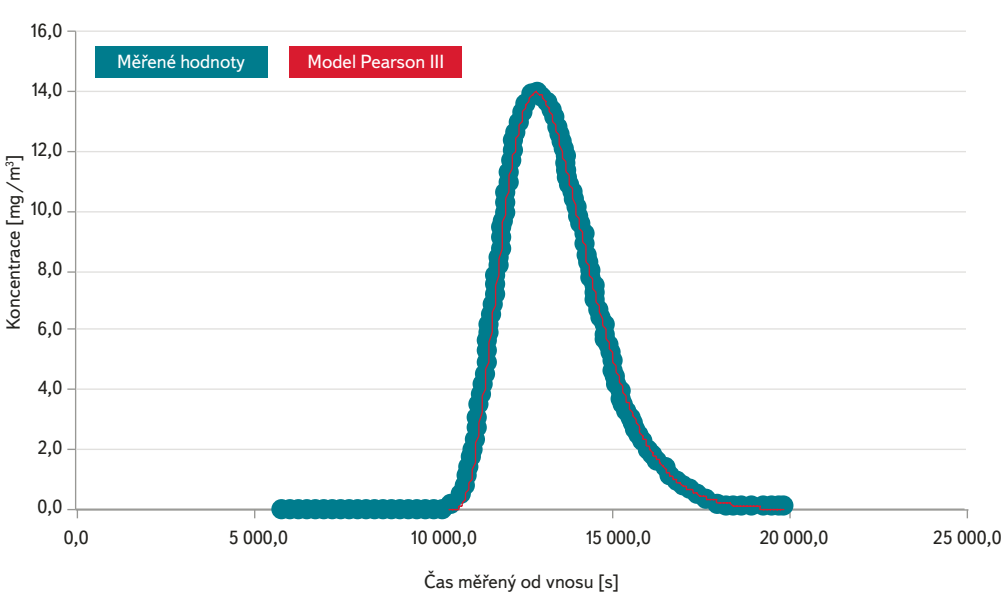

Obr. 5. Průniková Křivka - Svitava PF2 - srpen 2000

Fig. 5. Breakthroughcurve - Svitava PF2 - August 2000

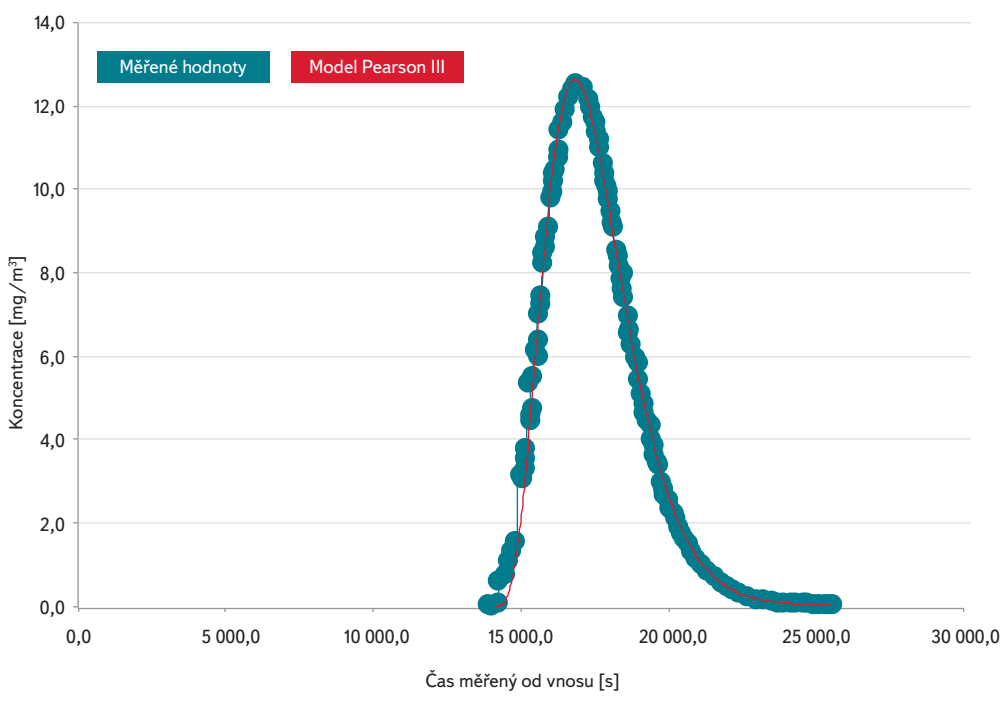

Obr. 6. Průniková krivka - Svitava PF21 - srpen 2000

Fig. 6. Breakthroughcurve - Svitava PF21 - August 2000

$V$ časech $t$ rovných nebo menších než $t_{B}$ předpokládáme, že profil nebude havarijním znečištěním ovlivněn. V prípadě, že se znečištujujicí látka vyskytuje $\checkmark$ toku běžně i před havárí bude nutno rovnici (5) ještě upravit i pro tuto variantu. $V$ prípadě, že znečištujuící látka, která unikla při havárii je nekonzervativní, Ize do rovnice (5) zavést ještě rychlostní konstantu objemových změn nebo rovnici zachovat $v$ původním stavu ve prospěch bezpečnosti odhadu. Pro jednotlivé profily na řece Svitavě je na obr. 2 až 6 provedeno porovnání naměěených hodnot $s$ modelem využívajícím Pearsonovo rozdělení II. typu. Vyvstává zde otázka, proč hledat zvláštní funkci pro aproximaci průnikových křivek (Pearson III), když funkční závislost za daných, výše uvedených předpokladů udává rovnice práce (1). Jedná se o snahu vyhnout se obtížnému stanovování koeficientu podélné disperze na základě proměnlivých parametrư řičního koryta. Podobnou snahu můžeme vidět napríklad i u tvưrců modelu Riverspiell [6], když zavedli novou metodu využívající implicitní korelaci mezi koeficientem podélné disperze a dotokovou dobou. Snaha vyhnout se prímé závislosti na proměnlivých parametrech koryta toku (průtočná plocha, šířka, hloubka) je patrná i u rovnice (1). 
Výsledky jsou shrnuty v tabulce 1. Koeficienty $a$ a $b$ v rovnici (5) byly získány metodou pokus omyl. Young a kol. [7] doporučili pro posuzování těsnosti mezi predikovanými a měřenými hodnotami vzorec pro výpočet koeficientu determinace. Pro naše potřeby byl použit ve formě rovnice (6).

$$
R_{t}^{2}=1-\frac{\sum_{i-1}^{p}\left(C_{i}-C_{M i}\right)^{2}}{\sum_{i-1}^{p}\left(C_{i}\right)^{2}}
$$

kde $R_{\mathrm{t}}$ je koeficient determinace $[-]$,

$C_{i} \quad$ i-tá hodnota měřené koncentrace $\left[\mathrm{mg} / \mathrm{m}^{3}\right]$,

$C_{\mathrm{Mi}} \quad$ i-tá hodnota koncentrace modelu $\left[\mathrm{mg} / \mathrm{m}^{3}\right]$,

$p \quad$ počet měření $v$ časech $t>t_{B}[-]$.

Autor Šajer [8] zjistil, že u všech pěti analyzovaných průnikových křivek Ize vzestupnou část průnikové křivky vyjádřit pomocí rovnice (7).

$$
\frac{C}{C_{p}}=0,5\left(1-\cos \left(\frac{\left(t-t_{B}\right) \pi}{t_{p}-t_{B}}\right)\right)
$$

kde $t$ je čas [s].

$\checkmark$ praxi se při vyhodnocování stopovacích pokusů zjištujuje čas $t_{L^{\prime}}$ pro který lze rovnici (7) upravit na rovnici (8).

$$
\left(t_{p}-t_{L}\right)=\frac{a(\pi-\arccos 0,8)}{\pi}
$$

Vezmeme-li v úvahu data, která uvádí Jobson v príloze [1], pak poměr mezi dobou potřebnou pro dosažení maximální koncentrace $C_{p} \vee$ zájmovém profilu, tj. ( $\left.t_{p}-t_{\alpha}\right)$, a dobou od vnosu po príchod do zájmového profilu, prí kterém je dosažena koncentrace jedna desetina maximální koncentrace $C_{p} \vee$ zájmovém profilu, tj. ( $t$ - $\left.-t_{2}\right)$, bývá blízko pod místem injektáže vyšší, s rostoucí vzdáleností se však většinou ustálí zhruba $\vee$ rozmezi $1,1: 1$ až 1,3: 1. Vyskytují-li se $\vee$ toku významné oblasti s pomalým prouděním (tzv. mrtvé zóny), pak je nutno počítat s vyššími hodnotami. Jako příklad je možno uvést poměr 1,68 : 1, který byl zjištěn u řeky Punkvy [9]. Uvedené poměry se týkají okamžitého vnosu konzervativní látky do toku.
Na základě uvedených výsledků budou do připravovaného modelu v povodí řeky Odry vloženy vstupní hodnoty tzv. defaulty, které bude možno na základě dalších zkušeností pro jednotlivé toky postupně upravovat.

Rovnice (1) až (5) je možno použít pouze v případě okamžitého vnosu zneČištující látky do toku. V praxi se často vyskytuje při haváriích kontinuální vnos s omezenou dobou trvání. $V$ tom případě Ize při modelování koncentrace $\checkmark$ zájmovém profilu vycházet z rozdělení pro okamžitý vnos (například z rovnice (5)) a následně použít metodu superpozice.

\section{ZÁVĚR}

Protože v poslední době nejsou v povodí Odry k dispozici žádná data ze stopovacích pokusů, byla pro prípravu modelu šíření znečištění v tomto povodí využita data ze stopovacích pokusů, které byly realizovány na Svitavě v roce 2000. Výsledné průnikové křivky se nejlépe podařilo popsat pomocí Pearsonova rozdělení 3. typu. Vychází se z analýzy pouze pěti průnikových křivek, pro zobecnění by bylo vhodné toto ověřit na dalších výsledcích z jiných stopovacích pokusů. Do připravovaného modulu $v$ povodí Odry budou vloženy defaulty vycházející z výše uvedených poznatků, které bude možno na základě dalších zkušeností pro jednotlivé toky postupně upravovat.

\section{Poděkování}

Tento príspěvek vznikl diky podpoře projektu č. TH02030142 NAVAROSO, pro který je poskytovatelem podpory Technologická agentura České republiky.

\begin{tabular}{|c|c|c|c|c|c|c|c|}
\hline Měsíc & Profil & $a$ [s] & b [s] & $\mathbf{R}_{t}^{2}$ & $t_{p}-t_{0}[s]$ & $a /\left(t_{p}-t_{0}\right)$ & $a / b$ \\
\hline červen & PF1 & 626 & 254 & 0,994 & 3031 & 0,207 & 2,465 \\
\hline červen & PF2 & 1542 & 365 & 0,996 & 8682 & 0,178 & 4,225 \\
\hline září & PF1 & 1212 & 362 & 0,999 & 4584 & 0,264 & 3,348 \\
\hline září & PF2 & 2441 & 598 & 0,998 & 12892 & 0,189 & 4,082 \\
\hline září & PF21 & 2678 & 678 & 0,997 & 16698 & 0,160 & 3,950 \\
\hline
\end{tabular}




\section{Literatura}

[1] JOBSON H.E Prediction of Traveltime and Longitudinal Dispersion in Rivers and Streams. I. Hydraut. 971-978. ISSN 073-9429.

[2] ŘíHA, J. a kol. Jakost vody v povrchových tocích a její matematické modelování. NOEL 2000, 2002 269 s. ISBN: 80-86020-31-2.

[3] Jos van Gils Development and maintenance of the Danube Basin Alarm Model [online 6. 12. 2017] Dostupné z: https://www.icpdr.org/flowpaper/viewer/default/files/2.2 DBAM-I_FinalReport.pdf

[4] ŘíHA, J., a STARA, V. Stopovací pokusy na řekách Svitavě a Svratce. Část I - Příprava, realizace a vyhodnocení stopovacích pokusü. Tracing experiments at the Svitava and Svratka rivers. Part 1 Preparation, implementation and analysis of results of tracing experiments). Vodni hospodárství \& ochrana ovzduši, 2002, č. 8, s. 227-230. ISSN 1210-4195.

[5] KŮRKOVÁ, I. Charakter proudění a šiření hydraulické odezvy ve vybraných jeskyních Moravského krasu. Diplomová práce. Karlova univerzita, Přírodovědecká fakulta, Praha, 2011. [online 6. 12. 2017] Dostupné z: https://is.cuni.cz/webapps/zzp/detail/67304/

[6] CHEHATA, M., BAHADUR, R., AMSTUDZ, E., and SAMUELS, W.B. Riverspill For Water Protection In The Potomac River Basin. [online 30. 3. 2017]. Dostupné z: http://eh2o.leidos.com/s
Transport/Surface/RiverSpill/Brochures/POSTER-AWRA-Potomac\%20RiverSpill.pdf

[7] YOUNG, P.C., JAKEMAN, A.J., and MCMURTRIE, R. An instrumental variable method for model order identification. Automatica, 1980, 16, p. 281-294. ISSN 0005-1098.

\section{[8] ŠAJER, J. Odhad času vnosu. VTEI, 2014, roč. 56, č. 3, s. 12-15. ISSN 0322-8916.}

[9] KNÍŽEK, M., KAMAS, J. a BRUTHANS, J. Nové stopovací zkoušky v Moravském krasu II: Podzemní Punkva v okolí Macochy (New tracer tests in the Moravian karst II: The Punkva underground rive
the surrounding of the Macocha Chasm.). Geol. výzk. Mor. Slez. v r. 2006, Brno, 2007, s. 113-116.

\section{Autor}

Ing. Jiří Šajer

凶jiri.sajer@vuv.cz

Výzkumný ústav vodohospodářský T. G. Masaryka, v. v. i., pobočka Ostrava

Příspěvek prošel lektorským řízením.

\section{INFORMATION ABOUT ORAM}

\section{SAJER, J.}

TGM Water Research Institute, p. r. i., Ostrava Branch

Keywords: accidental pollution - instantaneous spilll water quality - 1D modelling - Pearson distribution type 3

Odra River Alarm Modul (ORAM) will be part of the NAVAROSO project. There are no results of tracer studies of the Czech part of the Odra River in the last twenty years. That's the reason, why tracer experiment data of the Svitava River were used for analysis. This article is specifically focused on analysis of five breakthroughcurves. The best approximation of the breakthroughcurve in all five cases is given by equation (5) - Pearson distribution type 3. These results should be used by creation of ORAM.

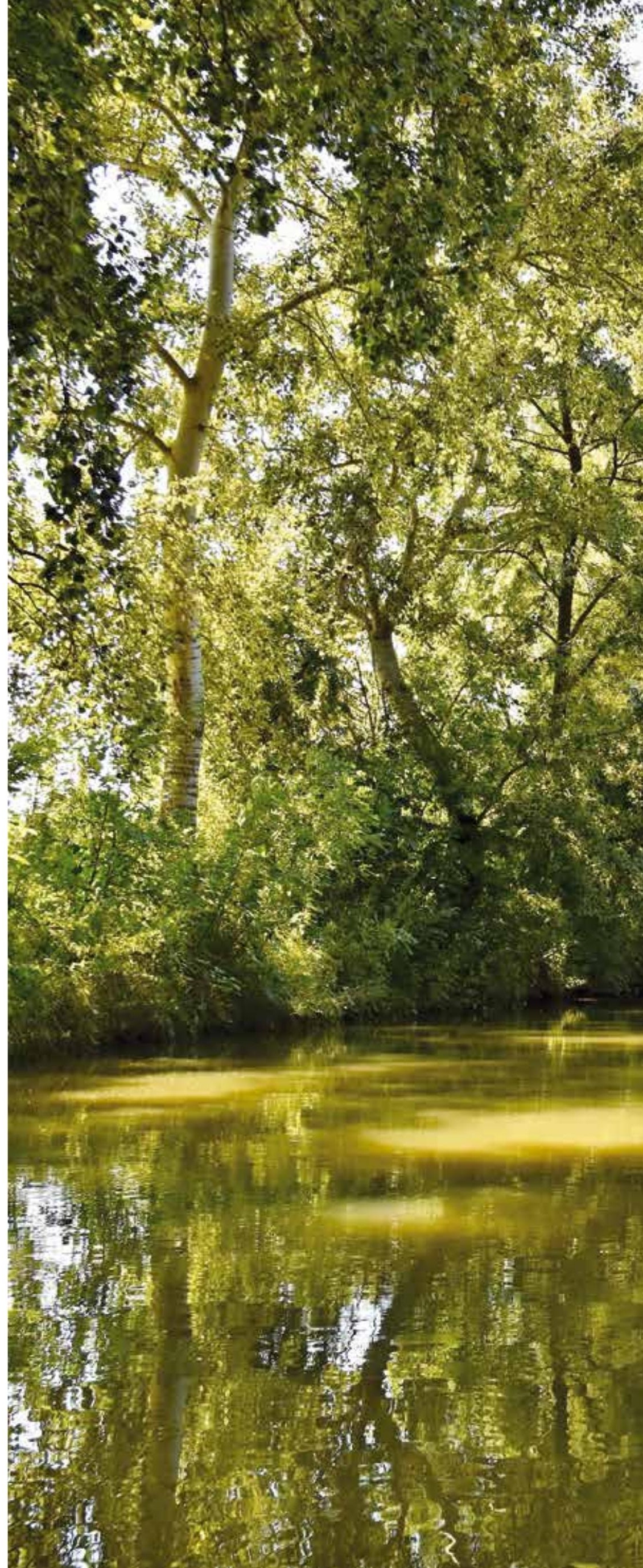

